\title{
Mariola Bieńko
}

Uniwersytet Warszawski

\section{INTYMNE ORAZ PRYWATNE GRANICE ZWIĄZKU KOBIETY I MĘŻCZYZNY}

\author{
INTYMNOŚĆ I PRYWATNOŚĆ JAKO PROJEKTY \\ WSPÓŁCZESNEJ RZECZYWISTOŚCI SPOŁECZNEJ
}

Najbardziej rozpoznawalnym znakiem przemian społecznych w warunkach późnej nowoczesności jest indywidualizacja i związana z nią pluralizacja stylów życia. Żyjemy obecnie w świecie, gdzie bardziej ceni się wolność osobistą i niezależność niż odpowiedzialność i współzależność. W kulturze narcyzmu samorealizacja jest kluczową wartością w życiu człowieka. Ona decyduje o moralnej ocenie różnych przedsięwzięć i poczynań, jej też podporządkowane jest tworzenie więzi z innymi ludźmi (Lash 1991; Sennett 2009). Wzrasta różnorodność prywatnych form życia. O realizowanym modelu związku interpersonalnego decyduje indywidualizm i silna potrzeba zaakceptowania prywatności. Współczesny związek uczuciowy to najczęściej system, w którym uwzględnia się subiektywne prywatne obszary każdego z jej członków (Janicka 2006: 22).

Późnonowoczesna przestrzeń społeczna w coraz większym stopniu wypełnia się uczuciami. Zmieniają się przy tym kody ich wyrażania - obserwuje się między innymi stopniową liberalizację ekspresji afektywnych w wyniku procesu emancypacji emocji (Wouters 2007). Według przedstawicielki amerykańskiej socjologii A. Russell Hochschild (2009: 85), na nasz prywatny system emocjonalny składają się emocje oraz reguły odczuwania i wymiany uczuć. Trudności w tej sferze wynikają często z nieumiejętności określenia granic obszarów intymności oraz prywatności w relacji z drugim człowiekiem. Prywatność wyraża pragnienie ograniczonej samotności.Intymność natomiast to ściśle chroniona, sekretna sfera, przeznaczona dla najbliższych. Oba pojęcia służą do opisania tej części życia, która jest kreowana i negocjowana w zaciszu codzienności oraz dziejących się w niej zwyczajnych, powtarzanych każdego dnia czynnościach.

Intymność ma ogromne znaczenie $\mathrm{w}$ zakresie funkcjonowania kobiety i mężczyzny w związku. Polski psycholog B. Wojciszke (1993: 8-11) uważa, że intymność jest, obok namiętności i zaangażowania, jednym z podstawowych 
składników miłości, czynnikiem poczucia szczęścia partnerów. Wiąże się ona ze specyfiką każdego związku, decyduje o jego odrębności i wyjątkowości. Jest ona także związana z zaufaniem i ujawnianiem siebie. Brytyjski socjolog D. Morgan wyróżnia trzy wymiary intymności, które dobrze obrazują intymny charakter relacji między kobietą i mężczyzną: 1) intymność zarówno fizyczna, jak i cielesna, w pewnym sensie seksualna. Zawiera fizyczną opiekę, więź (jej przejawy to przytulanie, trzymanie za ręce); 2) intymność emocjonalna, polegająca na dzieleniu się uczuciami, lękami, zainteresowaniami oraz 3) intymność jako pewna forma wiedzy, która tworzy granice między sferą prywatną i publiczną w życiu jednostki, a zarazem związku (Morgan 2009: 2). Intymność podtrzymują: otwartość, okazywanie uczuć, wsparcie, zrozumienie partnera, udział we wspólnych aktywnościach i rytuałach codziennego życia. (Segrin, Flora 2011: 140). Jeśli w trakcie trwania związku wzrasta wzajemne poznanie, umiejętność komunikowania się, udzielania wsparcia i pomocy - wzrasta też poziom intymności. Dynamika tego wzrostu jest powolna i łagodna.

Ujawnienie siebie, poznanie przez współpartnera mocnych i słabych stron niosą jednak ze sobą większe ryzyko głębokiego zranienia. „Być ze sobą blisko, ale nie za blisko, tak, by każdy zachował pewną niezależność - oto ideał zgodny z kierunkiem zmian w rodzinie, które określa się jako jej kryzys", twierdzi brytyjski historyk, filozof i socjolog Th. Zeldin (1998: 432). Tradycyjne reguły, które rządziły związkami osobistymi, przestały obowiązywać, a jednostki stają dziś wobec konieczności wyboru spośród nieskończonej liczby możliwości tworzenia, poprawy, a także rozwiązywania swoich relacji uczuciowych z innymi. Wydaje się, że w zakresie relacji intymnych zapanował dziś pewien chaos, który przejawia się $w$ decyzjach, wyborach, umowach, codziennej prozaicznej pracy nad więziami. Przedstawiciele niemieckiej socjologii U. Beck i E. Beck-Gernsheim (1995) sugerują, że jedną z cech „nowej ery w stosunkach intymnych” jest kolizja interesów między miłością, rodziną i osobistą wolnością.

Wywiązywanie się z podjętych zobowiązań prywatnych nie wystarcza do poczucia samorealizacji i szczęścia jednostki. Istotą związku jest płynność, ruch, nieuchwytność, czyli po prostu ciągłe tworzenie więzi. W codziennej praktyce mężczyzna i kobieta tworzą komplementarnie uzupełniającą się parę. Wytwarzane w intymnych związkach „wspólne narracje biograficzne” stają się częścią refleksyjnych projektów tożsamościowych i są utrzymywane w takim stopniu, w jakim pasują do planów życiowych obojga partnerów (Giddens 2001). Dzisiaj kobieta i mężczyzna odczuwają potrzebę bycia częścią „my” bez poświęcenia własnego ,ja”, tj. poczucia siebie jako odrębnej i autonomicznej jednostki. Polski socjolog Z. Bauman przestrzega przed ideą „oczyszczenia” związku ze wszelkich funkcji, z wyjątkiem tej polegającej na dawaniu wzajemnej satysfakcji, gdyż rodzi to, jego zdaniem, „szereg nieszczęść, udręk i cierpień oraz stale rosnącą liczbę złamanych ludzkich istnien, pozbawionych miłości i perspektyw na przyszłość" (Bauman 2006: 139). 
W zindywidualizowanym społeczeństwie dokonuje się transformacja intymności. Ewolucja postaw widoczna jest w zmianie relacji osobistych, często negocjowanych. Zwiększa się zakres prywatności, a przede wszystkim intymności człowieka jako usankcjonowanej kulturowo wartości w obrębie oczywistego niegdyś funkcjonowania w zalegalizowanym związku. Wielu współczesnych badaczy wskazuje na to, że „rodzina” nie jest już „naturalnym” czy biologicznym zjawiskiem, ale małą kulturą powstającą w wyniku różnych praktyk dyskursywnych (Gordon 2009: 28). Małżeństwo, będące dawniej ogniwem rodziny z całą siecią osób partycypujących, jest coraz częściej procesem negocjowanych relacji stron. Co trzeci mieszkaniec Europy Środkowej rozwodzi się. Nastąpiła deinstytucjonalizacja małżeństwa, jest ono dzisiaj w kulturze zachodniej związkiem intymnym o charakterze woluntarystycznym, a nie obligatoryjnym. Jeszcze na początku XX wieku idealny związek zmieniał „dwie osoby w jedną”, podczas gdy w XXI stuleciu stał się relacją dwóch, zupełnie odrębnych osobowości. O powstaniu rodziny zaczyna zatem decydować zjawisko, które brytyjski socjolog A. Giddens (1998: 140-149) nazywa emocjonalnym indywidualizmem.

Związek intymny zyskuje na znaczeniu w biografii jednostki, jest coraz ważniejszy dla kształtowania jej tożsamości. Trudniej jest go dzisiaj zbudować, ponieważ wzrosły wymagania w stosunku do ogólnej jakości wzajemnych relacji uczuciowych. Ludzie dążą przez małżeństwo do osobistego szczęścia i instytucja ta coraz częściej szczęście to zapewnia. Obserwuje się procesy emocjonalizacji i intymizacji wewnętrznej struktury rodziny. Osłabienie tradycji i silnych zobowiązań w życiu społecznym zbiega się ze wzrostem indywidualnej wolności, a przede wszystkim szansy wyboru pomiędzy różnymi formami międzyludzkiego współżycia. Wskazuje się na wzrastającą ambiwalencję wartości małżeństwa i jego prywatyzację. Małżeństwo przypomina układ partnerski, w którym obie strony pragną zachować swoją autonomię. Partnerstwo zostaje zdefiniowane przez emocjonalne spełnienie i ciągły proces porozumiewania się. Ideał jednostkowej tożsamości oraz dwustronnego związku partnerskiego stanowią jeden połączony projekt. Większość ludzi oczekuje od małżeństwa romansu, intymności oraz poczucia spełnienia. Pragną partnerstwa opartego na zupełnej równości. Ideał małżeństwa to dwoje ludzi bezustannie wzrastających w miłości, zrozumieniu i jedności oraz spełnianiu wzajemnych potrzeb. Terapeuci twierdzą, że ludzie tak naprawdę kochają to, co ich partnerzy robią dla nich w odpowiedzi na ich najgłębsze pragnienia i potrzeby (Wenning 2001: 16).

Analizując przemiany zachodzące w nowoczesnym świecie można postawić tezę, że, wzrastający proces indywidualizacji pociąga za sobą swoiste ,uwalnianie" od tradycyjnych ról mężczyzny i kobiety. W myśl tej tezy role płci poddać można kulturowej refleksji. Większość mężczyzn nie oczekuje po małżeństwie więcej niż ich ojcowie. Zmiany są bardziej widoczne w pokoleniu współczesnych kobiet. Wiele z nich, wychowywanych na poświęcające się dla innych mediatorki, rewiduje zasady swego wychowania i żąda więcej i od siebie, i od partnerów. 
Po II wojnie światowej obserwuje się w kulturze zachodniej zjawisko „nowego erotyzmu", znamionującego przegrupowanie postawy wobec heteroseksualności i wzajemności relacji. Przyznanie prawa do przyjemności seksualnej kobiety wywołała zmiany w kierunku równości i wolności w parze (Brooke 2011: 70). W kulturze masowej podkreślany jest wyraźnie potencjał każdej osoby do realizowania się poza tradycyjnie pojmowaną moralnością dotyczącą związków czy intymnych relacji. Zjawisko to obejmuje wszelkie formy seksu, miłości lub rodziny, które nie zawsze opierają się na klasycznej monogamii. „Konfiguracja” wydaje się trafniej opisywać uczuciową rzeczywistość niż „związek”, biorąc pod uwagę postulaty oderwania się od normatywizacji emocji oraz intymności (Easton, Hardy 2012: 18-19).

Intymność nie istnieje poza kulturą, poza symbolami, których znaczenie poznajemy w drodze socjalizacji, jest społecznym tworem służącym społecznym celom. Sfera kontaktów intymnych we współczesnej kulturze staje się „projektem” podlegającym optymalizacji, kulturową praktyką regulowaną przez mechanizmy rynkowe, dyskursy naukowe i medialne oraz najnowsze technologie komunikacyjne. Za sprawą wszechpanującego w kulturze narcyzmu przeżycia uznawane za intymne stały się dziś towarem. Mamy do czynienia z pozorną otwartością i skomercjalizowaną intymnością (Muszyński 2009: 11-12). Coraz więcej ludzi rozsianych po całym świecie wchodzi w rodzinne relacje, porozumiewając się na Facebooku, Twitterze i przez Skype'a. Można, parafrazując tytuł ostatniej książki Becka i Beck-Gernsheim (2013) nazwać ten typ zapośredniczonej bliskości, intymnością na odległość. W sieci znane jest pojęcie „bliskości w tle”. Ambient intimacy oznacza bycie w ciągłym, bliskim kontakcie z innymi, zarówno w sprawach ważnych, ale przede wszystkim w sprawach błahych, codziennych. Być związanym z kimś „bliskością w tle” to być obecnym w jego życiu ze swoją upublicznioną prywatnością online. Odwoływanie się do słów, znaczeń i kontekstów znanych tylko wybranej publiczności, sprawia, że możliwy jest ten niezwykły rodzaj publicznej intymności (Wanke 2011: 290-291).

Małżeństwo, rodzina, partnerstwo stają się miejscami, w których sprzeczności zmodernizowanego społeczeństwa rynkowego skierowane w sferę prywatną z trudem bywają rekompensowane (Beck 2002: 179). Współcześnie uważa się, że reformie świata prywatnego powinna towarzyszyć reforma świata publicznego. W efekcie neoliberalnej rewolucji więzy solidarności społecznej, które miały stabilizować towarzyszącą ludzkiemu życiu niepewność, zastąpił rynek z ofertą rozwiązań dostosowanych do indywidualnych potrzeb. Dziś kontekstem dla intymności i wolności jest neoliberalizm i będąca jego podstawą ideologia wolnego wyboru oraz wolnego rynku. Intymność pod naporem sił ewoluującego kapitalizmu staje się jedną z form aktywności ekonomicznej, której celem jest maksymalizacja użyteczności (Zelizer 2005). Relacje intymne są w kulturze przedmiotem idealizacji i problematyzacji. Intymność, zarówno 
w wymiarze fizycznym, jak i emocjonalnym staje się katalizatorem nowego społeczeństwa. Według L. Irigiray (2000), demokracja rodzi się w relacjach partnerskich w parze.

\section{ZWIĄZKI INTYMNE W PERSPEKTYWIE BADAWCZEJ}

Badacze społeczni z trudem wkraczają na kłopotliwe, obciążone emocjonalnie terytorium intymności. Zjawisko to często nieuchwytne na pierwszy rzut oka, możliwe jest do opisania dopiero po bardzo gruntownej analizie jednostkowych przypadków. Na użytek artykułu przedstawię wąski wycinek wyników badań, będących częścią szerszej analizy empirycznej na temat intymności. Badania, przeprowadzone w Warszawie w okresie od 2003 do 2011 roku, miały na celu uzyskanie zróżnicowanego materiału analitycznego w obszarze zdefiniowania pojęcia intymności oraz wskazania elementów budujących relacje intymne. Proces badawczy składał się z trzech etapów: zbierania definicji intymności, wywiadów indywidualnych i wywiadów grupowych (fokusów) na temat wybranych aspektów intymności w związkach dorosłych partnerów ${ }^{1}$. Podstawą refleksji badawczych zawartych $\mathrm{w}$ artykule będzie analiza wybranych wypowiedzi osób, które wzięły udział w wywiadach indywidualnych.

Najodpowiedniejszym sposobem doboru osób do badań interpretacyjnych, realizującym moje zamierzenia badawcze opisania głębi i różnorodności doświadczenia intymności, okazała się "strategia kuli śnieżnej” (snowball strategy). W wywiadach wzięło udział 52 osoby ( 25 kobiet w wieku od 23 do 71 lat i 27 mężczyzn w wieku od 22 do 68 lat). Mieszkały one w Warszawie, posiadały wyższe lub średnie wykształcenie, studiowały, pracowały zawodowo lub były na emeryturze. Wszystkie pozostawały w związkach nieformalnych lub związkach małżeńskich, 33 osoby posiadały dzieci, 18 osób - wnuki. Wywiady trwały od 40 minut do ponad trzech godzin; w większości przypadków czas ten wynosił około 1,5 godziny.

Podjęte przeze mnie badania miały charakter jakościowy, biorący pod uwagę poglądy subiektywne, podmiotowe, dostępne przy użyciu techniki wywiadu swobodnego. Zastosowałam jakościowy wywiad badawczy na wpół uporządkowany (semistructured interview) jako skuteczną metodę uchwycenia przeżywanych sensów świata codzienności badanych, przekazanych z ich własnej perspektywy i własnym codziennym językiem (Kvale 2004:79). Przygotowany zestaw pytań otwartych, czyli scenariusz wywiadu potraktowałam jak listę kontrolną. Forma pytań i ich porządek ulegał zmianie zależnie od kontekstu rozmowy. W dyspozycjach do wywiadu pojawiły się kwestie konkretnego doświadczania oraz praktykowania intymności w życiu codziennym. Głównym celem wywiadów było wskazanie elementów budujących relacje w związkach intymnych osób dorosłych obojga płci.

\footnotetext{
${ }^{1}$ Szerszy zakres opisywanych badań przedstawiony jest w książce: Bieńko (2013).
} 


\section{Między bliskością a dystansem w intymnym związku}

Bazą, na której konstruuje się pozytywną więź jest zdolność przeżywania intymnej relacji, jednak większość naszego życia spędzamy sami ze sobą, niezależnie od tego gdzie i z kim żyjemy. Umiejętność dystansu jest niezbędna do budowania dorosłych relacji. Jak twierdzi przedstawicielka amerykańskiej socjolingwistyki D. Tannen (2002: 122), w każdym bliskim związku należy znaleźć miejsce właściwe w układzie - czyli odpowiednią pozycję między bliskością i dystansem. Bliskość chroni nas przed samotnością, a dystans przed nadmiernym zespoleniem: Wszystko jest kwestia dystansu między ludźmi. Kiedy sa zbyt blisko, duszq się, kiedy sa zbyt daleko, odchodza $(35 / \mathrm{k} / 70)^{2} ;[\ldots]$ żona i ja ciuchy mamy na oddzielnych pótkach. Podobno w Chinach matżonkowie nie zagladaja do swoich szaf [...], bo jeżeli nie ma żadnych granic, to jesteśmy wystawieni na nieustanny kontakt $(28 / \mathrm{m} / 49) ;[\ldots]$ otwierać, czy nie otwierać drzwi do toalety - oto jest pytanie! [...] Możemy przecież zachować granice $w$ parze, sikając sobie wspólnie w tazience. To nie jest obowiazkowe: sikanie - osobno, jedzenie-razem, [...] oczywiście, jest jakaś norma, wzorzec kulturowy dopuszczalnych granic, ale to nie oznacza, że musimy się do niego sztywno stosować $(25 / \mathrm{m} / 39) ;[\ldots]$ w udanym związu intymność nie ma granic (41/m/68); Intymność to bycie blisko kogoś, bycie w tym kimś, w jego świecie, a nawet bycie światem kogoś drugiego (19/k/31); Intymność to zakleszczenie erotyczno-duchowo-intelektualne, które pozwala na rozwój w zwiazku (37/m/60); Rozkoszne stopienie się w jedno, Zaburzenie granic między nami, zamazanie mojego ,ja” $(15 / \mathrm{k} / 32)$.

Bliskość, główny komponent intymności, daje poczucie bezpieczeństwa, ale może też je odebrać, co trafnie wyraża polskie słowo „dotknąć” - być blisko, a zarazem zranić, znając najsłabsze strony bliskiej osoby. Prawdziwa intymność, w interpretacji badanych osób, często ma charakter „namacalny”. Symbole intymności, deklarowane zarówno przez badane kobiety, jak i mężczyzn to gesty fizycznej (cielesnej) intymności (uścisk, dotyk, pocałunek). Dotyk, zwłaszcza według mężczyzn, jest niezbędny do osiagnięcia intymności $(8 / \mathrm{m} / 42)$. Według kobiet, [...] dotyk, któremu brak uczucia i przywiazania, jest jedynie fizycznym aktem, nie ma nic wspólnego z intymnościa $(1 / \mathrm{k} / 30)$. Fizyczna bliskość może co prawda natychmiast zaspokoić pożadanie, ale nie stworzy atmosfery intymności (23/k/58). Wymieniane w badanej grupie „organoleptyczne” przejawy intymności to na przykład kapanie się z kimś; jedzenie z tego samego talerza; szeptanie, mamrotanie do ucha; skubanie włosów partnera; czytanie wspólne gazety, ksiązki; bycie w jednej toalecie; obserwowanie, jak mężczyzna goli się, a kobieta depiluje okolice intymne; odczuwanie naturalnego zapachu drugiej osoby.

${ }^{2}$ Symbole w nawiasie przy cytowanych wypowiedziach to kod każdej z osób badanych: oznaczenie numeru osoby według kolejności przeprowadzania wywiadów/płeć/wiek. 
Zarówno intymność emocjonalna, jak i seksualna oraz cielesno-zmysłowa jest, zdaniem badanych, sprawą ryzykowna, gdyż oznacza zdjęcie szlabanów i ukazanie partnerowi swoich wrażliwych miejsc i najtajniejszych sekretów $(12 / \mathrm{m} / 45)$. Badane kobiety i mężczyźni podkreślają, że w sytuacji intymności jest się najbardziej bezbronnym. Związki uczuciowe są ciągłym źródłem zagrożenia dla poczucia własnej wartości, ponieważ postrzegane są jako wyraz wnikliwej oceny naszej osoby przez innych. Świadome ujawnienie siebie, poznanie przez partnera zarówno naszych zasobów, jak i wszelkich deficytów może, jak twierdzą badani, spowodować zdemaskowanie nas takich, jacy naprawdę jesteśmy, a w konsekwencji wywołać upokorzenie: Intymność wzbudza często niepokój, w intymnej relacji stajemy się bardziej wrażliwi. Boimy się, że partner przejrzy nas na wylot. [...] Istnieje ryzyko, że nie zachowa dla siebie twoich tajemnic i że będzie cię osqdzat [...], że zdradzi twoje zaufanie i że ośmieszy twoje marzenia $(34 / \mathrm{k} / 27)$.

Jak twierdzą badane kobiety i mężczyźni, intymność wymaga gotowości podejmowania ryzyka, że będziemy widziani w związku bez pozorów i udawania, mających na celu zadowolić innych i zaspokoić ich oczekiwania: Niektórzy z nas obawiaja się, że gdy za bardzo zbliżmy się do innych, okaże się, jacy naprawde jesteśmy. [...] Może się okazać, że nie jesteśmy atrakcyjni i że ludzie nie chcieliby nawiazywać z nami stosunków, gdyby naprawdę nas znali (11/k/39); Intymność to zdjęcie maski, pokazanie słabości. Bliska i głęboka intymność obnaża nas takimi, jakimi naprawde jesteśmy (16/m/54); Nie wszyscy chcemy sie psychicznie rozebrać. Przychodzi jednak czas, kiedy musimy dostownie $i$ w przenośni rozebrać się. [...] Stosunki intymne bezwstydnie odkrywaja nasze tajemnice, wykluczaja transakcje, maskarady $(28 / \mathrm{m} / 49)$.

U kobiet stała emocjonalna bliskość jest niezbędnym komponentem intymności: [...] jest zadowoleniem nie tyle z tego, jaki partner jest, ale z tego wtaśnie, $\dot{z}$ e jest obok i nikogo nie udaje. Jest też świadomościa, że pozostajemy odrębnymi, niezależnymi osobami, które stwarzają coraz większy obszar wspólnego doświadczania $i$ przeżywania [...] $(24 / \mathrm{k} / 54)$. W wypowiedziach badanych mężczyzn częściej niż w wypowiedziach kobiet ujawnia się poczucie zagrożenia, lęk przed byciem odkrytym i zranionym lub niechęć do rezygnacji z władzy nad partnerem w intymnym związku: Tak bardzo boimy się bliskości, że we efekcie niewiele od siebie wymagamy, nawet $w$ zakresie miłości $i$ intymności - spłaszczamy te sytuacje, żeby raczej nic nie przeżywać niż być zranionym $w$ swoich uczuciach $(26 / \mathrm{m} / 41$ lat); [...] odstaniasz przed partnerem w tej intymności, jak kot, swoje miękkie podbrzusze i juz nie ty rozdajesz karty (13/m/52); Im bardziej pozwalamy się zblizyć komuś do siebie, im bardziej zrastamy się z innym czlowiekiem, tym mniej skutecznie możemy kontrolować sytuację (18/m/31); Dostaję odpatu, jak jest zbyt intymnie w związku, to znaczy coraz blizej, coraz więcej zwierzeń itp. $(10 / \mathrm{m} / 34)$; Intymność to straszna rzecz - przez lata budowateś zbroję, a ktoś wchodzi do twojego środka bez ostrzeżenia, może tam coś pokręcić - w twoim sercu, mózgu, w ogóle 
- życiu. Jesteś zakładnikiem jakiejś osoby, czujesz się z tym źle, a zarazem tęsknisz do tego (31/m/57); Intymność włazi ci pod skórę i rozrywa na kawatki, a ty jeszcze o to prosisz. Przestajesz być panem swojego losu $(47 / \mathrm{m} / 24)$.

W interpretacji badanych kobiet i mężczyzn, prawdziwa bliskość jest wzajemną otwartością i wzajemną akceptacją. „Zdjęcie masek” może być pozytywne i korzystne dla jednostki i związku pod warunkiem wzajemnego zaufania: Intymność jest kluczem do świata drugiego człowieka (4/k/23); [...] dopuszczasz druga osobę do swojej osobistej przestrzeni emocjonalnej bez poczucia zagrożenia, gdyż wcześniej sprawdziliście się dobrze i nabraliście petnego wzajemnego zaufania (20/k/51). Intymność jest sferą odkrywania samego siebie: Intymność pozwala gtęboko oddychać $w$ zwiazku, a nie dusić się $w$ nim, zaktadając jakieś koszmarne maski $[\ldots](8 / \mathrm{m} / 42)$. W relacjach intymnych możemy odmitologizować ideat samych siebie. Możesz tam pokazać się drugiemu człowiekowi najuczciwiej, jak się da. [...] Intymność polega na tym, że można być niedoskonatym i prawdziwym bez usprawiedliwienia $(41 / \mathrm{m} / 68)$; Intymność to bycie prawdziwym $w$ obecności drugiej osoby i pozwolenie mu na to samo. Nikt nie walczy w tej sytuacji o kontrole nad soba i uczuciami. Akceptacja, bliskość, zaufanie [...] - to intymność (21/k/36); Mogę się dzielić tylko z taka osoba, której będę mogła bezgranicznie zaufać, która nie „,wywlecze” tej mojej intymności na światto dzienne (4/k/23); Prawdziwa intymność polega na tym, że przy mężu mogę pokazywać wlasna słabość i nie trzeba przy tym nic wyjaśniać ani tłumaczyć. [...] Nie musze gasić światta, żeby ukryć twarz bez makijażu lub fatdy thuszczu (33/k/56); „Wtopieni w kogoś” nie musimy przejmować się własna niedoskonatościa. Przeglądamy się $w$ kimś jak $w$ lustrze (39/k/25); [...] to jest wtaśnie piękne. Jeżeli pozbędziemy się strachu przed bliskościa, nauczymy się akceptować siebie takimi, jakimi jesteśmy (5/k/40).

Dużo w tym dążeniu do bliskości napięć, zmagań i chaosu panującego w relacjach. Zbyt duża zażyłość może prowadzić do związku nadmiernie intymnego, jak twierdzą badani. Może nawet zagrozić jego istnieniu. Być ze soba blisko, ale nie za blisko, tak, by każdy zachowat pewna niezależność $(17 / \mathrm{m} / 59)$ - oto ideał określany przez badane osoby. Światowe badania pokazują, że mężczyźni deklarują na ogół wyższy poziom odczuwanej w związku intymności niż ich partnerki (Segrin, Flora 2011: 122). W interpretacji badanych przeze mnie mężczyzn, intymność może stać się zbyt bliska i przytłaczająca lub powodować w ich przypadku nadmierną defensywność: Intymność to bycie blisko ale na bezpieczna odległość $(44 / \mathrm{m} / 30)$; Bycie w związu nie może być zmuszaniem się do ciagłego przebywania razem. To samo myślimy, to samo czujemy w tej samej sekundzie. Takie połaczenie może mieć katastrofalne skutki. Taka wspólnota to tylko złudzenie idealnego zwiazku, to ściema. Intymność to czasem kłótnie.

Zdaniem niektórych badanych, głównie mężczyzn, intymność może być opresyjna, jeśli traktowana jest jako wymóg stałej bliskości partnerów: [...] Intymność nie jest też stała obecnościa przy partnerze $(9 / \mathrm{k} / 24)$. Za duża gotowość do bliskości bez granic wzbudza nieufność, że szybko zostanę zjedzony (29/m/44); 
Nie potrafię pójść na catość w związku, może z lęku przed psychicznym potknięciem przez kobietę (47/m/24); Ludzie przestaja się pragnać, gdy sa ze soba zbyt blisko $(40 / \mathrm{m} / 28)$. Niezwykle ważna, w interpretacji badanych kobiet i mężczyzn, jest umiejętność wypracowania dynamicznej równowagi między wzajemną bliskością a indywidualną odrębnością każdego z partnerów w związku.

Intymność to doświadczenie przestrojenia się na rzeczywistość innej osoby, a zarazem ryzyko zmiany samego siebie przez to doświadczenie. Zakres znaczenia słowa ,intymność" oscyluje w wypowiedziach badanych pomiędzy erotyzmem - bliskością cielesną a bliskością emocjonalną i duchową. Gesty fizycznej (cielesnej) intymności mają różne znaczenia dla kobiety i mężczyzny. Dla zdecydowanej większości badanych „intymność” znaczy „,bliskość”. Ten rodzaj więzi $\mathrm{z}$ partnerem pogłębianej w trakcie intymnych spotkań ma dla kobiet szczególne znaczenie. Bardziej cenią one emocjonalną stronę związku, budowanie z partnerem relacji opartej na otwartości, zaufaniu, akceptacji i bliskości. Badani mężczyźni częściej z kolei podkreślają, że w sytuacji intymności jest się najbardziej bezbronnym. Ujawnienie siebie, poznanie przez współpartnera mocnych i słabych stron niesie ze sobą ryzyko zranienia. W związku intymnym zarówno badane kobiety, jak i mężczyźni obawiają się zdemaskowania i upokorzenia.

\section{Dylematy prywatności i autonomii w intymnym związku}

Intymność jest dla badanych przeżyciem bardzo osobistym: W pewnym sensie intymność jest moja własna przestrzenia, gdzie znajduja się moje marzenia, problemy, kompromitacje, doły życiowe, czasem wariactwa $(46 / \mathrm{m} / 22)$; Intymność to sfera osobista, która dotyczy najbardziej prywatnych spraw, dopuszcza sie do niej w niektórych sytuacjach tylko zaufanych ludzi (11/k/39). W interpretacji badanych kobiet i mężczyzn, życie w związku oznacza permanentne napięcie pomiędzy intymnością a autonomią: Intymność to radyklany atak na wyobrażenia o naszej wtasnej autonomii $(12 / \mathrm{m} / 45) ;[\ldots]$ jest problem, bo w matżeństwie intymność pozwala przezwyciężyć poczucie izolacji i samotności, a jednocześnie powinniśmy pozostać soba $(32 / \mathrm{k} / 64) ;[\ldots]$ to spotkanie się dwóch osób, ale bez zatracenia swej odrębności. Trzeba chronić swoje prawo do autonomii i szanować samotność drugiej osoby (42/k/38); Intymność polega na wspólnym przebywaniu ze soba, ale niezależność $i$ świadomość wtasnej autonomii jest niezbędna, by się nie zatracić w zwiąku (13/m/52); Intymność napawa mnie pewna melancholia, ponieważ $w$ związu zostawiamy za soba to, co jest częścia nas samych, [...] trochę znikamy, aby zaistnieć jako para $(48 / \mathrm{m} / 71)$.

W zakresie ,praktykowania intymności” przez badane osoby, podstawowym dylematem jest określenie niezależności, wolności, przestrzeni osobistej oraz przestrzeni wspólnej zarówno w związku, jak i w sobie: Sztuka jest być ze sobq blisko, ale zarazem dać sobie margines wolności (2/m/26); Intymność może sprawić, że przebywajac ze soba dostatecznie dlugo, wzajemnie na siebie wptywamy 
i w pewien sposób odnajdujemy w sobie coś więcej z drugiego, a mniej z siebie. [...] Próbujac kogoś wchtonać, sprawiamy, że on znika (6/m/32); Ludzie nie moga sobie wypetniać każdej szczeliny w życiu. Musza sobie dać przestrzeń. [...] Trzeba coś niewinnego zostawić tylko dla siebie, żeby nie zostać dostownie i w przenośni gotym [...] (34/k/27); Intymność nie może oznaczać „,sklejenia emocjonalnego” (7/k/33); Intymność to danie sobie i jemu miejsca, czasu i prawa do samotności w zwiazku (23/k/58); Moja dziewczyna buduje swoje światy, do których mnie nie wpuszcza. [...] jest też moja przestrzeń wewnętrzna z zakazem wjazdu $(18 / \mathrm{m} / 31)$.

Niezależnie od płci i wieku osób badanych, nawet zwolennicy bardzo bliskiej więzi uważają, że konieczne jest zachowanie granic w związku: Para, nie określając granic, nie ma prawa czuć się bezpiecznie i intymnie (11/k/39); Intymność nie polega na ,zlaniu się” z druga osoba [...] (6/m/32); Intymność to mieszkanie $w$ drugim człowieku, ale konieczne jest zbudowanie ścian, pewnych granic ciata i psychiki. Bez tego nie wchodze w żaden układ z żadna kobieta $(25 / \mathrm{m} / 39)$. Pytanie, które nurtuje badane osoby dotyczy tego, czy granice $w$ związu sa zbyt szczelne i zamknięte, albo odwrotnie, czy nie sa zbyt „dziurawe”. A może nie masz ich w ogóle i pozwalasz, by twoja tożsamość była tożsamościa partnera? (27/k/43); Intymność to granica, do której przekroczenia dopuszczam tylko nielicznych (28/m/49); Trzeba uważać, żeby intymność nie stała się „,roztopieniem” $w$ zwiazku, w partnerze, to musi być prywatna gra kontrolowana $z$ wyznaczeniem regul, zasad, granic $(47 / \mathrm{m} / 24)$.

Tworzymy związek z każdym, z kim udałoby się stworzyć odpowiednią ilość prywatnych znaczeń. O to, czy granice prywatności staną się utrudniającymi raczej niż ułatwiającymi komunikację podziałami, decyduje wypracowana w związku równowaga między otwartością na partnera, obawą przed zranieniem a wzajemnym zaufaniem: Intymność to coś w rodzaju uczciwości emocjonalnej. [...] Każdy ma delikatne obszary, które wymagaja ochrony. Intymność to wtaśnie znajomość tych obszarów u drugiej osoby i nie naruszanie ich (35/k/70); Mam nadzieję, że esencja prywatności - moja osobowość, będzie rozpoznawalna. Wiem, co czujesz nie dlatego, że mi o tym mówisz, ale ponieważ czuję to samo $(5 / \mathrm{k} / 40)$; Każdy musi mieć swoja prywatność. W dobrym zwiazku każdy musi mieć coś swojego. Inaczej nie ma mowy o intymności. To cementuje zwiazek. W zwiazku groźne jest tłamszenie prywatności, indywidualności. Gdy rezygnujesz z części siebie, niewiele masz do zaoferowania drugiej osobie $(10 / \mathrm{m} / 34)$; Intymność to bycie ze soba, nienaruszające niczyjej prywatności $(16 / \mathrm{m} / 54)$.

Prywatność chroni ważne dla jednostki wartości. Uczestnicy wywiadów byli zgodni co do tego, że w związku z partnerem, należy bronić własnej wolności, indywidualności, która przeplata się z pragnieniem bliskości: $W$ tym całym bałaganie trudno dojrzeć dwie normalne, wolne osoby. [...] wyznania, emocje, namiętności wywoluja napięcie, a czasem prawdziwe tragedie (22/k/45). Prywatność kojarzy się potocznie ze swobodą, niezależnością, większymi możliwościami "bycia sobą", z szansą na pełniejszą realizację własnych upodobań, kształtowa- 
niem sytuacji według własnej woli i na miarę własnych pragnień: Najgorsze jest zawłaszczenie osobistego terytorium. Każdy musi mieć swoja prywatność, takie miejsce, gdzie może pobyć sam ze soba, coś przemyśleć, popłakać, zatęsknić; Każ$d y$ człowiek potrzebuje wokót siebie prywatnej przestrzeni, niewidzialnego kokonu, który ma mu zapewnić poczucie bezpieczeństwa $(20 / \mathrm{k} / 51)$.

Pomiędzy bliskością emocjonalną i otwartością a prywatnością partnerów w związkach istnieje odwrotna proporcjonalność. Pragnieniem kobiet, biorących udział $\mathrm{w}$ wywiadach, jest zostać w pełni odkrytą, poznaną, zrozumianą przez partnera. Badane kobiety, chcąc utrzymywać ważne dla nich relacje osobiste i społeczne, częściej niż mężczyźni deklarują, że są gotowe zrezygnować, przynajmniej częściowo, z własnej prywatności: Matżeństwo zaspokaja potrzebę catkowitego otwarcia się na siebie, nieskrępowanie i luz we własnym domu, moge chodzić w gaciach przy mężu i to mnie nie krępuje. Świat partnera staje sie jakby światem wtasnym, oswojonym, dajac poczucie bezpieczeństwa i zaufania [...] $(24 / \mathrm{k} / 54)$; Nie można być z kimś blisko, nie ujawniając osobistych czy prywatnych szczegótów na swój temat (21/k/36); Intymność oznacza wymianę, a wymiana oznacza rezygnację z części prywatności. [...] $W$ związu równie niebezpieczna i niewyobrażalna bytaby totalna prywatność $(4 / \mathrm{k} / 23)$.

Badani przyznają, że myśląc o założeniu rodziny liczyli się z tym, że to ograniczy ich prywatność. Takie obawy pojawiały się częściej w wypowiedziach mężczyzn niż kobiet. Jednocześnie częściej w wypowiedziach badanych mężów i ojców widoczna jest chęć wkraczania w prywatność innych domowników. Jak twierdzą, zdarza im się czytać korespondencję żony, pamiętniki własnych dzieci, przeglądać zawartość ich telefonów komórkowych. Częściej mężczyźni niż kobiety skłonni są zapoznawać się z osobistymi dokumentami pozostałych członków rodziny, np. notatkami, wynikami badań lekarskich. Mężczyźni zastanawiali się, czy można uznać założenie osobistego konta w banku przez partnerkę za jej prywatną sprawę, czy też raczej za rodzaj finansowej, osobistej nielojalności wobec męża. Badane kobiety wyraźnie podkreślały osobisty, nienaruszalny obszar prywatności w zakresie dysponowania własnym budżetem w ramach małżeństwa.

Niemiecki socjolog i filozof G Simmel przekonywał, że całkowity brak tajemnic może całkowicie zrujnować związek - nie pozostanie nic wartego dociekań. Posiadanie sekretów wspólnych z partnerem i swoich sekretów osobistych, świadczy o pewnej dozie prywatności jednostki. Wyniki wielu analiz badawczych pokazują, że posiadanie wspólnych sekretów wzmacnia związek (Segrin, Flora 2011: 63). Jak twierdzi jedna z badanych kobiet, Nie ma nic bardziej tajemniczego niż intymność (35/k/70). Kobiety w porównaniu z mężczyznami częściej w kontekście intymności mówią o sekretach, tajemnicach, które dzielą z partnerem, a są wstydliwie ukrywane przed innymi: Seks to dla nas zbyt intymna sprawa, zebyśmy chcieli powiadamiać o niej wszystkich sąsiadów (43/k/46); Ważna w intymności jest chyba gotowość do uczuciowej bezbronności, utraty prywatności i ujawnienia 
sekretów. Zdradzając tajemnice, budujemy wzajemne zaufanie (19/k/31); Intymność to posiadanie tajemnic, wspólne sekrety (22/k/45); Intymność opiera się na zwierzeniu innym swojego wnętrza, swojej tajemnicy (34/k/27).

Analiza wywiadów pokazuje, że wcale nie chodzi o to, żeby w związku nie mieć nic do ukrycia. Kobiety podkreślały konieczność posiadania „swoich” sekretów w związku: Mówimy to, co konieczne, ale akceptujemy pewna dawke sekretów. Lubię szczerość, ale z dawka zdrowego rozsądku. Intymność, życie wewnętrzne powinno być pod ochrona, gdy zna się niebezpieczeństwo pozostania „pustym”, bez osobistych tajemnic, ,wysprzedanym” (5/k/40). Mężczyźni z kolei twierdzą, że intymność to zdrowa równowaga między zbyt małą i zbyt dużą otwartością w bliskich relacjach: Trzeba wiedzieć, kiedy przestać gadać o wszystkim. Zwierzając się, obciązamy innych naszymi tajemnicami. [...] Kiedy dzielimy się z innymi tym, co uważamy za najbardziej intymne, a nawet wstydliwe, to dowiadujemy się, że wszyscy tak maja [...] (52/m/43). W interpretacji badanych mężczyzn, zwłaszcza rozmowy o odczuciach związanych z aktywnością seksualną w związku, to obszar zwierzeń „sekretnych”, wyjątkowo osobistych i prywatnych: Można je porównać do psychologicznego rozbierania się przed druga osoba $(12 / \mathrm{m} / 45)$.

W kilku przypadkach kobiety wspominają o wyraźnym naruszeniu granic, kiedy opresyjny charakter intymności deklarowany jest w kontekście przemocy i agresji w bliskim związku: To straszne: zniknęłam, wyparowałam, rozpłynętam się w tej intymności matżeńskiej [...] Jeśli kobieta angażuje się w zwiazek, gotowa jest na tak wiele poświęceń, że może nawet nie zauważyć, że rezygnuje ze swojego życia. I to właśnie nazywa intymnościa: rezygnację z godności, akceptację przemocy, naruszanie jej granic [...] (36/k/50); [...] czasami w związu ktoś sobie wyobraża, że intymność oznacza posiadanie władzy nad partnerem, przemoc staje się wtedy rodzajem niebezpiecznej, ale bardzo intymnej komunikacji... bo przemoc jest intymna, często nieujawniana i wstydliwa .... (2/k/26); Mężczyźni nie potrafią być delikatni, czuli. Intymność może być przemoca [...] (7/k/33).

Zaprzeczeniem intymności, zdaniem badanych, jest zawłaszczenie partnera. Intymność nie powinna być ograniczeniem mojej przestrzeni [...]. Stabe jest zakleszczenie się $w$ zwiąku na amen. Intymność, oprócz innych rzeczy: miłości, seksu, otwartości, bla, bla, bla [...] to także wolność oprócz oczywiście bliskości, otwartości, nagości fizycznej i psychicznej (7/k/33); Nowoczesny zwiazek opiera się na autonomii własnego życia. Prawdziwa intymność nie jest dostosowaniem się do wymagań nawet najbliższej nam osoby, nie jest układem, w którym rezygnujemy z kawałka siebie w zamian za miłość, akceptację (12/m/45).

W interpretacji badanych kobiet i mężczyzn, utrzymywanie długotrwałych związków nie jest łatwe, ponieważ konieczne jest wówczas tworzenie i zachowywanie równowagi pomiędzy odrębnością a wspólnotą: 40 lat w związu, jak moi dziadkowie to nie żarty, nie wiem, czy dałabym radę. Trzeba ćwiczyć każdego dnia 
tę intymność [...]. Ograniczona wolność wiąże się z ograniczona otwartościa, [...] nieograniczona szczerość grozi problemami. Nie powinno się całkowicie rezygnować z siebie. [...] Brak granic może osłabiać moja tożsamość (15/k/32); Coś trzeba stracić, poświęcić, zapłacić pewna cenę za to szczęście. [...] Stajemy przed wyborem stopnia, do jakiego jesteśmy w stanie zrezygnować z naszej prywatności - odkrycia naszych tajemnic, żeby móc prowadzić życie emocjonalne $(48 / \mathrm{m} / 71)$. Jak twierdzą w większości badani, intymność jest niezaprzeczalną wartością w związku, ale [...] jej ciężar może przygnieść. [...] uzależnieni od partnera, musimy bronić własnej wolności, indywidualności (1/k/30). Wytyczając autonomiczne obszary życia, każdy zapewnia sobie możliwość dzielenia lub nie pewnych chwil z innymi: Nienawidzę i boję się prawdziwej intymności - to rozrywanie du$\operatorname{szy}(3 / \mathrm{m} / 40)$.

Badani obojga płci, definiując intymność, określają ją jako bliską relację interpersonalną zachodzącą pomiędzy dwojgiem osób, które dobrze się znają i odczuwają swobodę w ujawnianiu swych najskrytszych uczuć. Sama intymność, trudna do zdefiniowania, rozumiana bywa intuicyjnie jako kwintesencja tego, co najbardziej prywatne, wstydliwe i ukryte głęboko w świadomości jednostki. $\mathrm{W}$ badanych związkach istnieją granice intymności dopuszczalne przez partnerów, których nie należy przekraczać. Pewna doza seksualnej i emocjonalnej ekskluzywności ma tu ogromne znaczenie.

Zarówno kobiety, jak i mężczyźni uważają, że relacje są intymne w zależności od stopnia wiedzy niedostępnej dla osób trzecich. Na wiedzę składają się takie elementy jak: wspólne sekrety, wzajemne rytuały, język ciała, świadomość wspólnej pamięci oraz doświadczeń. W ujęciu badanych kobiet i mężczyzn, intymność to bycie prawdziwym w obecności partnera i pozwolenie mu na to samo. Co prawda przedstawiciele obu płci przyznają, że intymność to akceptacja, bliskość i zaufanie, jednak mężczyźni częściej niż kobiety walczą w tej sytuacji o kontrolę nad wzajemnymi relacjami.

\section{REFLEKSJE KOŃCOWE}

Intymność oraz życie uczuciowe od zawsze były głównymi źródłami niepewności i ryzyka w życiu kobiet i mężczyzn. Komunikacja w intymnym związku zakłada otwartość, wynikającą ze wzajemnego zaufania i odczuwanej bliskości. Jednocześnie bliskość i wzajemne poznanie może prowadzić również do wykorzystywania partnera lub umiejętnego nim manipulowania. Dlatego niezbędne jest, aby każda ze stron zachowała pewien obszar prywatności, dzięki któremu nie dochodzi do wzajemnego uzależnienia od siebie.

Bycie w intymnym związku oznacza proces, w którym szukamy zbliżenia się do partnera interakcji, poznania analogii (i różnic) w sposobach myślenia, 
odczuwania, zachowania. Kluczowym problemem w tej relacji jest wytyczenie granic fizycznych i emocjonalnych, swoistych wysp wyłączności w ,intymnym krajobrazie" związku. Badane przeze mnie kobiety i mężczyźni wskazują na dynamiczne współoddziaływanie, a niekiedy sprzeczność pomiędzy intymnością $i$ autonomią. W ich wypowiedziach, intymność jest tym samym co granice związ$\mathrm{ku}$ - nieprzekraczalne dla obcych i niezbędne dla partnera. Wyrazem emocjonalnej dojrzałości jest poszukiwanie we wzajemnych kontaktach równowagi między separacją i unią, indywidualizmem i zależnością.

W warunkach indywidualizacji i rozpadu więzi międzyludzkich ochrona prywatności, osobistej przestrzeni i koncentracja na sobie jest przejawem skłonności narcystycznych, które skłaniają jednostkę do postrzegania wszelkich zdarzeń zewnętrznych w kontekście zindywidualizowanego znaczenia. Świadomość, że bycie razem opiera się na w pełni dobrowolnej decyzji sprawia, że partnerzy w większości czują się wolni i niezależni. Dotyczy to głównie deklaracji kobiet. Badani mężczyźni częściej wskazują na element lęku przed wdaniem się w intymną relację. Ich wypowiedzi oscylują między poczuciem bycia posiadanym, związanym i zmierzającym do utraty własnej osobowości a potrzebą ucieczki W poszukiwaniu niezależności. W wypowiedziach badanych kobiet i mężczyzn z jednej strony, zwiększający się w czasie dystans fizyczny wobec partnera może zaszkodzić, z drugiej zaś element autonomii może być wręcz dobrodziejstwem dla wzajemnych relacji w stałym związku.

Badani testują granice intymności w związkach: jak zyskać zaufanie i używać kompromisu, zachowując własną odrębność, jak lubić się i przyjaźnić, zachowując intymność. Na początku poprzedniego stulecia Simmel pisał:

W małżeństwie i podobnych mu wolnych związkach czai się pokusa, aby w pierwszym okresie wchłonąc się nawzajem całkowicie, aby odsłoniwszy przed partnerem wszystkie tajniki ciała odsłonić przed nim także tajniki duszy, zatracić się bez reszty w drugiej osobie. Takie postępowanie jednak każe przeważnie obawiać się o przyszłość związku (Simmel 2008: 179).

Przejście od ,ja” do „my” to jeden z podstawowych i, jak się okazuje uniwersalnych, aspektów wzajemnych bliskich relacji.

W opisywanych przez badane kobiety i mężczyzn intymnych związkach rodzi się napięcie między chęcią przynależenia a potrzebą zachowania maksymalnej autonomii. Pragną bliskości w relacji z partnerem, a jednocześnie deklarują silną potrzebę niezależności. Można zobrazować ten nierozwiązywalny konflikt integracji-separacji, posługując się metaforą z udziałem dwóch jeżozwierzy próbujących przetrwać mroźną zimę: Przytulają się do siebie, żeby było im cieplej, ale kłują się ostrymi igłami, więc muszą się odsunąć i wtedy jest im zimno. Chcąc się ochronić przed mrozem i przed pokłuciem igłami współtowarzysza, jeżozwierze muszą wyważyć dzielący je dystans - źródło komfortu i przykrości zarazem (Tannen 2002). 


\section{BIBLIOGRAFIA}

Bauman Z. (2006), Płynna nowoczesność, przeł. T. Kunz, Wydawnictwo Literackie, Kraków.

Beck U. (2002), Społeczeństwo ryzyka. W drodze do innej nowoczesności, przeł. S. Cieśla, Wydawnictwo Naukowe SCHOLAR, Warszawa 2002.

Beck U., Beck-Gernsheim E. (1995), The Normal Chaos of Love, przeł. M. Ritter i J. Wiebel, Polity Press, Cambridge.

Beck U., Beck-Gernsheim E. (2013), Miłość na odległość. Modele życia w epoce globalnej, przeł. M. Sutowski, Wydawnictwo Naukowe PWN, Warszawa.

Bieńko M. (2013), Intymne i prywatne praktyki codzienności. Studium socjologiczne, Wydawnictwa Uniwersytetu Warszawskiego, Warszawa 2013.

Brooke S. (2011), Sexual Politics. Sexuality, Family Planning, and the British Left from the 1880s to the Present Day, Oxford University Press, Oxford.

Easton D., Hardy J.W. (2012), Puszczalscy z zasadami. Praktyczny przewodnik dla miłośników poliamorii, otwartych zwiazków i innych przygód, przeł. R. Madejski, Wydawnictwo Czarna Owca, Warszawa.

Giddens A. (2001), Nowoczesność i tożsamość. „Ja” i społeczeństwo w epoce późnej nowoczesno$s ́ c i$, przeł. A. Szulżycka, Wydawnictwo Naukowe PWN, Warszawa.

Giddens A. (1998), Socjologia. Zwięzłe, lecz krytyczne wprowadzenie, przeł. J. Gilewicz, Zysk i S-ka, Poznań.

Gordon C. (2009), Making Meanings, Creating Family. Intertextuality and Framing in Family Interaction, Oxford University Press, Oxford-New York.

Hochschild A. R. (2009), Zarządzanie emocjami. komercjalizacja ludzkich uczuć, przeł. J. Konieczny, Wydawnictwo Naukowe PWN, Warszawa.

Irigiray L. (2000), Democracy Begins Between Two, przeł. K. Anderson, Routledge, New York.

Janicka I. (2006), Kohabitacja a matżeństwo w perspektywie psychologicznej. Studium porównawcze, Wydawnictwo Uniwersytetu Łódzkiego, Łódź.

Kvale S. (2004), InterViews. Wprowadzenie do jakościowego wywiadu badawczego, przeł. S. Zabielski, Trans Humana, Białystok.

Lasch Ch. (1991), The Culture of Narcissm. American Life in an Age of Diminishing Expectations, W.W. Norton, New York.

Morgan D. (2009), Acquaintances: The Space Between Intimates and Strangers, Open University Press, Maidenhead.

Muszyński W. (2009), Związki uczuciowe w cywilizacji konsumpcyjnej, [w:] W. Muszyński (red.), „Kocha się raz?” Miłość w relacjach partnerskich i rodzinnych, Wydawnictwo Adam Marszałek, Torun.

Segrin Ch., Flora J. (2011), Family Communication, Routledge, New York-London.

Sennett R. (2009), Upadek człowieka publicznego, przeł. H. Jankowska, Warszawskie Wydawnictwo Literackie Muza, Warszawa.

Simmel G. (2008), Psychologia dyskrecji, [w:] Pisma socjologiczne, przeł. M. Łukasiewicz, Oficyna Naukowa, Warszawa.

Tannen D. (2002), To nie tak! Jak styl konwersacyjny ksztattuje relacje z innymi, przeł. P. Budkiewicz, Zysk i S-ka, Poznań.

Tannen D. (2002), Mówię to, bo cię kocham, przeł. P. Budkiewicz, Wydawnictwo Zysk i S-ka, Poznań.

Wanke M. (2011), E-mocje, przypadki rozszerzonej rzeczywistości afektywnej, [w:] A. Czerner, E. Nieroba (red.), Studia z socjologii emocji. Podręcznik akademicki, Wydawnictwo Uniwersytetu Opolskiego, Opole. 
Wenning K. (2001), Mężczyźni są z Ziemi i kobiety sa z Ziemi, przeł. A. Fita, Gdańskie Wydawnictwo Psychologiczne, Gdańsk 2001

Wojciszke B. (1993), Psychologia miłości. Intymność. Namiętność. Zaangażowanie, Gdańskie Wydawnictwo Psychologiczne, Gdańsk.

Wouters C. (2007), Informalization. Manners and Emotions since 1890, Sage Publications, Los Angeles-London-New Delhi-Singapore.

Zeldin T. (1998), Intymna historia ludzkości, przeł. B. Stokłosa, Wydawnictwo W.A.B., Warszawa. Zelizer V. A. (2005), The Purchase of Intimacy, Princeton University Press, Princeton and Oxford.

\section{Streszczenie}

Tematem rozważań w artykule jest fenomen związków intymnych w okresie późnej nowoczesności. Istotne miejsce $\mathrm{w}$ rozważaniach zajmują analizy empiryczne dotyczące jakościowego opisu indywidualnego i pozornie nieprzekazywalnego doświadczenia intymności między kobietą i mężczyzną. Płeć partnerów jest ważną zmienną, która decyduje o możliwości zaistnienia intymności oraz jakości ich wzajemnych relacji. Źródłem analizy jest zbiór osobistych narracji partnerów pozostających w związkach.

Prawdziwym wyzwaniem dla badaczy intymności jest określenie pojęciowego zakresu tego zjawiska. Zastosowanie jakościowego podejścia badawczego pozwoliło na zebranie danych dotyczących obszarów prywatności oraz intymności w bliskich związkach. Podstawą badań był proces mapowania wskaźników i rozkładu pojęć związanych ze zjawiskiem intymności. Pogłębione wywiady indywidualne pozwoliły na przedstawienie przez osoby badane doświadczeń składających się na proces „tworzenia intymności”. Przeprowadzone analizy ujawniły cztery główne obszary „praktykowania” intymności - w sferze emocjonalnej, seksualnej, cielesnej i duchowej.

Słowa kluczowe: intymność, prywatność, związek, płeć, kobieta, mężczyzna, kultura.

\section{Intimate and private boundaries of the relationship of man and woman}

\section{Summary}

Following article discusses the phenomenon of intimate relationships in terms of advanced modernity. The research segment plays a significant role in this article; it provides a qualitative description of the seemingly impossible to convey, individual experience of intimacy in a dyad. Gender of the partners is a contextual variable that affects their opportunities for intimacy and the quality of their intimate interactions. The analysis draws from configurations of personal narratives of partners in couple relationships.

A dilemma for scholars who study intimacy is deciding on the best way to conceptualize it. Using a semi-structured approach allowed to gain data around such issues like privacy and intimacy in close relationships. The foundations of research was the process of mapping the rates and distribution of what are assumed to be intimacy phenomenon. A series of in-depth individual interviews were conducted with respondents to explore their experiences of "doing intimacy". The main findings showed a repertoire of the practices of intimacy in four main areas - emotional, sexual, physical and spiritual.

Keywords: intimacy, privacy, relationship, gender, woman, man, culture. 